\title{
The occurrence of noncoagulating milk and the association of bovine milk coagulation properties with genetic variants of the caseins in 3 Scandinavian dairy breeds
}

\author{
N. A. Poulsen,${ }^{* 1}$ H. P. Bertelsen, $\dagger$ H. B. Jensen, ${ }^{*}$ F. Gustavsson, $\ddagger$ M. Glantz, $\ddagger$ H. Lindmark Månsson, $₫ \S$ \\ A. Andrén,\# M. Paulsson, $\ddagger$ C. Bendixen,† A. J. Buitenhuis,† and L. B. Larsen* \\ ${ }^{*}$ Department of Food Science, and \\ †Department of Molecular Biology and Genetics, Faculty of Science and Technology, Aarhus University, DK-8830 Tjele, Denmark \\ ‡Department of Food Technology, Engineering and Nutrition, Lund University, PO Box 124, SE-221 00 Lund, Sweden \\ §Swedish Dairy Association, SE-223 70 Lund, Sweden \\ \#Department of Food Science, Swedish University of Agricultural Sciences, SE-750 07 Uppsala, Sweden
}

\begin{abstract}
Substantial variation in milk coagulation properties has been observed among dairy cows. Consequently, raw milk from individual cows and breeds exhibits distinct coagulation capacities that potentially affect the technological properties and milk processing into cheese. This variation is largely influenced by protein composition, which is in turn affected by underlying genetic polymorphisms in the major milk proteins. In this study, we conducted a large screening on 3 major Scandinavian breeds to resolve the variation in milk coagulation traits and the frequency of milk with impaired coagulation properties (noncoagulation). In total, individual coagulation properties were measured on morning milk collected from 1,299 Danish Holstein (DH), Danish Jersey (DJ), and Swedish Red (SR) cows. The 3 breeds demonstrated notable interbreed differences in coagulation properties, with DJ cows exhibiting superior coagulation compared with the other 2 breeds. In addition, milk samples from $2 \%$ of $\mathrm{DH}$ and $16 \%$ of SR cows were classified as noncoagulating. Furthermore, the cows were genotyped for major genetic variants in the $\alpha_{S_{1}-}(C S N 1 S 1), \beta-(C S N 2)$, and $\kappa$-casein $(C S N 3)$ genes, revealing distinct differences in variant frequencies among breeds. Allele $I$ of CSN2, which had not formerly been screened in such a high number of cows in these Scandinavian breeds, showed a frequency around $7 \%$ in DH and DJ, but was not detected in SR. Genetic polymorphisms were significantly associated with curd firming rate and rennet coagulation time. Thus, CSN1S1 C, CSN2 B, and CSN3 $B$ positively affected milk coagulation, whereas CSN2 $A^{2}$, in particular, had a negative effect. In addition to the influence of individual casein genes, the
\end{abstract}

Received November 27, 2012.

Accepted April 22, 2013.

${ }^{1}$ Corresponding author: Nina.Poulsen@agrsci.dk effects of CSN1S1-CSN2-CSN3 composite genotypes were also examined, and revealed strong associations in all breeds, which more or less reflected the single gene results. Overall, milk coagulation is under the influence of additive genetic variation. Optimal milk for future cheese production can be ensured by monitoring the frequency of unfavorable variants and thus preventing an increase in the number of cows producing milk with impaired coagulation. Selective breeding for variants associated with superior milk coagulation can potentially increase raw milk quality and cheese yield in all 3 Scandinavian breeds.

Key words: milk coagulation, genetic polymorphism, protein composition, composite genotype

\section{INTRODUCTION}

Rennet-induced milk coagulation is central in the process of cheesemaking and is correlated with cheese yield and overall cheese quality (Ikonen et al., 1999b; Wedholm et al., 2006). Therefore, improved cheese milk is of interest to the dairy industry for optimal cheese production. However, substantial variation has been reported in milk coagulation capacity among individual cows, which influences processing and requires the addition of unwanted additives. Rennet-induced milk coagulation is a 2-phase process, including enzymatic hydrolysis of $\kappa-\mathrm{CN}$ followed by aggregation of $\mathrm{CN}$ micelles and gel formation (Green and Morant, 1981; Walstra, 1990; Fox and McSweeney, 1998). A wide range of factors affect milk coagulation in individual cows, including cow aspects such as health status, lactation stage, and parity (Tyrisevä et al., 2003; Ikonen et al., 2004), as well as the content and relative proportions of the caseins $\left(\alpha_{\mathrm{S1}^{-}}, \alpha_{\mathrm{S}^{-}}, \beta-\right.$, and $\left.\kappa^{-} \mathrm{CN}\right)$ and whey proteins in milk (Jõudu et al., 2008). Furthermore, recent studies have indicated that posttranslational modifications of $\alpha-\mathrm{CN}$ may also play a role in milk coagulation together with micelle size and mineral balance, primarily through 
levels of calcium (Hallén et al., 2010; Frederiksen et al., 2011a; Jensen et al., 2012b) and small metabolites (Sundekilde et al., 2011).

Several genetic variants of the major milk proteins have been identified in cattle (Farrell et al., 2004; Caroli et al., 2009), and overall protein composition and milk coagulation are partly influenced by the milk protein genes (Lundén et al., 1997; Ikonen et al., 2004). The influence of additive genetic variation on cheese-making capacity and coagulation properties is evident in $\beta-\mathrm{LG}$, $\beta-\mathrm{CN}$, and $\kappa-\mathrm{CN}$ (Marziali and Ng-Kwai-Hang, 1986; Ikonen et al., 1999a; Wedholm et al., 2006; Hallén et al., 2007; Meza-Nieto et al., 2007). In particular, several studies have demonstrated that cows with variant $B$ in the $\kappa_{-}$-CN gene (CSN3) have been consistently associated with desirable coagulation properties by exhibiting increased curd firmness, resulting from higher CN and protein content (Ikonen et al., 1997; Mayer et al., 1997; Buchberger and Dovc, 2000; Hallén et al., 2007; Jõudu et al., 2007).

Interbreed differences in coagulation properties have been reported (De Marchi et al., 2007), and Frederiksen et al. (2011b) documented superior coagulation properties in Danish Jersey (DJ) compared with Danish Holstein (DH) and Danish Red cows. In some breeds, impaired coagulation properties of individual milk samples have high prevalence (Tyrisevä et al., 2004; Wedholm et al., 2006; Hallén et al., 2007; Cassandro et al., 2008), and Ikonen et al. (2004) reported that $13 \%$ of Finnish Ayrshire cows produced noncoagulating (NC) milk. The prevalence of $\mathrm{NC}$ milk is suspected to be partly under genetic influence (Ikonen et al., 1999a), and negative associations between $C S N 3 E$ and milk coagulation properties have been documented in different breeds (Ikonen et al., 1999a; Wedholm et al., 2006; Hallén et al., 2007).

Previous studies documenting NC and poorly coagulating milk from DH and Swedish Red (SR) have been conducted on a limited number of animals (Wedholm et al., 2006; Frederiksen et al., 2011b). Therefore, the objectives of the current study were to provide robust estimates of milk coagulation properties in 3 common Scandinavian dairy breeds by screening 2 coagulation traits: rennet coagulation time (RCT; s) and curd firming rate $(\mathbf{C F R} ; \mathrm{Pa} / \mathrm{min})$ in a large number of animals. Furthermore, the effects of individual CN composite genotypes on coagulation properties were examined to provide a comprehensive understanding of the relative contribution of casein genes to milk coagulation traits.

\section{MATERIALS AND METHODS}

\section{Milk, Blood, and Tissue Samples}

This study was conducted as part of the DanishSwedish Milk Genomics Initiative. Blood, tissue, and morning milk samples were collected from $456 \mathrm{DH}$ (20 dairy herds, October to December 2009), 436 DJ (22 dairy herds, February to April 2010) and 407 SR (19 herds, April to May 2010 and September 2010 to April 2011). Individual milk samples were analyzed for SCC using flow cytometry by Fossomatic 5000 (Foss Analytical, Hillerød, Denmark) at Eurofins Laboratory, Holstebro, Denmark, for DH and DJ and Eurofins Laboratory, Jönköbing, Sweden, for SR. After exclusion of milk samples with high SCC (>500,000 cells/mL; $37 \mathrm{DH}, 26 \mathrm{DJ}$, and $6 \mathrm{SR}$ ) and missing rheological or genotypic data, a total of $417 \mathrm{DH}, 408 \mathrm{DJ}$, and $367 \mathrm{SR}$ had combined coagulation and genotype profiles. These cows were the daughters of $218 \mathrm{DH}, 144 \mathrm{DJ}$, and 159 SR sires with the number of daughters per sire ranging from 1 to 17 in $\mathrm{DH}$ and DJ, and 1 to 16 in SR. The overall experimental design underlying this study minimized potential sources of environmental variation and ensured a low degree of genetic relatedness among cows in the sample population. Sampling was carried out at conventional (nonorganic) herds during the indoor period. All cows were housed in loose housing systems, fed according to standard practices, and milked twice daily and occasionally 3 times daily (see Poulsen et al., 2012). Parity and lactation stage at sampling were known for all cows. Milk yield at the particular milking was recorded, and representative milk samples of at least $0.5 \mathrm{~L}$ were placed on ice during transport to the laboratory. Swedish milk samples were cooled for $24 \mathrm{~h}$ during transport to the laboratory in Denmark, but were otherwise treated identically. Immediately after sampling, milk samples were aliquoted, skimmed (centrifuged for $30 \mathrm{~min}, 2,643 \times g$ at $4^{\circ} \mathrm{C}$ ), and refrigerated at $5^{\circ} \mathrm{C}$ for up to $6 \mathrm{~h}$ without preservatives before being subjected to rheological analysis. Fat and protein percentages were determined on fresh whole milk samples by MilkoScan FT2 (Foss Analytical).

\section{Rheological Analyses}

Rennet-induced coagulation of individual milk samples was determined by dynamic rheological analyses using a ReoRox4 rheometer (MediRox AB, Nyköping, Sweden). Briefly, the sample cup was set into free oscillation and amplitude damping and frequency change were measured continuously for $1 \mathrm{~h}$ after addition of chymosin, essentially as described by Frederiksen et al. (2011b). All skim milk samples were adjusted with lactic acid to $\mathrm{pH} 6.5 \pm 0.02$ before rheological analyses. The coagulant used was Chy-Max Ultra (pure chymosin, Chr. Hansen, Hørsholm, Denmark) with 194 international milk clotting units (IMCU)/ $\mathrm{mL}$. Chymosin was diluted 10 times, and added to the milk sample at onset of the coagulation measurement, 
resulting in a final concentration of $0.04 \mathrm{IMCU}$ per $\mathrm{mL}$ in the sample cup. Each milk sample was measured in technical duplicates, and the coagulation properties for individual samples were described as RCT and CFR using ReoRox software (version 1.5.0.1055). Rennet coagulation time was defined as the time from chymosin addition to the time when the phase angle was $45^{\circ}(\theta=$ $45^{\circ}$ ). Curd firming rate was calculated from consecutive points of the linear part of the gelation profile $\left[\Delta \mathrm{G}^{\prime} /\right.$ $\Delta \mathrm{t}]_{\text {lin }}$, thereby describing the average storage modulus $\mathrm{G}^{\prime}$ over time in minutes(see Frederiksen et al., 2011b). Maximum gel strength was not applied as a trait, because the gelation profile for several samples did not achieve maximum gel strength within the measuring period. Samples that did not coagulate within $1 \mathrm{~h}$ after chymosin addition were considered $\mathrm{NC}$ milks as they did not exhibit a recordable RCT and had a CFR of 0 . Several samples demonstrated very poor coagulation properties, revealed as 1 recordable measurement and 1 $\mathrm{NC}$ in duplicate measurements. This included 1 sample in DJ, 11 in DH, and 37 in SR. These samples were excluded from the NC prevalence estimates but included in the binomial statistics in relation to $\mathrm{NC}$ milks as described below.

\section{Genotyping Genetic Variants}

Genomic DNA was purified from blood (SR) or ear tissue (DH and DJ) utilizing the BioSprint 96 workstation (Qiagen, Hilden, Germany), according to manufacturer's protocols for blood and tissue samples. Samples were treated with protease followed by isopropanol precipitation, and DNA was purified by means of magnetic-particle technology. All animals were genotyped for major reported genetic variants of $\alpha_{S_{1}}$ CN (CSN1S1), $\beta-C N(C S N 2)$ and CSN3 genes (Farrell et al., 2004; Caroli et al., 2009) using custom Taqman SNP genotyping assays (Applied Biosystems, Foster City, CA). Three assays were constructed to distinguish between the $C S N 1 S 1 B, C, D$, and $F$ variants. Furthermore, an assay was constructed to identify the deletion in the CSN1S1 A variant (Supplementary Table S1; http:// www.journalofdairyscience.org/; Mohr et al., 1994). Four assays were developed to discriminate between CSN2 variants $A^{1}, A^{2}, A^{3}, B$, and $I$ (Supplementary Table S1), and finally 4 assays were constructed to distinguish between the genetic $C S N 3$ variants $A, B$, and $E$ (Supplementary Table S1). The DNA was dried and a mix comprising $0.05 \mu \mathrm{L}$ of Assaymix, $1.95 \mu \mathrm{L}$ of TaqMan Universal PCR Master Mix No AmpErase UNG, and $2 \mu \mathrm{L}$ of $\mathrm{H}_{2} \mathrm{O}$ was added to each well in a 384-well plate (all reagents from Applied Biosystems). The following program parameters were used for PCR: $50^{\circ} \mathrm{C}$ for $2 \mathrm{~min}$; initial denaturation at $95^{\circ} \mathrm{C}$ for $10 \mathrm{~min}$; amplification of DNA by 40 cycles of denaturation at $95^{\circ} \mathrm{C}$ for $15 \mathrm{~s}$; and annealing and elongation at $60^{\circ} \mathrm{C}$ for 1 min. Following PCR amplification, an Allelic Discrimination Plate Read was performed with the ABI-PE prism 7900 sequence detection system (Applied Biosystems) and data were analyzed using SDS 2.1 software (Applied Biosystems).

\section{Statistical Analysis}

All animals having NC milk in one or both rheological duplicates were removed before statistical analyses. The effects of breed, parity, and DIM on RCT and CFR were estimated by use of the following single-trait general linear model:

$$
\begin{aligned}
\mathrm{Y}_{\mathrm{ijk}}= & \mu+\text { breed }_{\mathrm{i}}+\text { parity }_{\mathrm{j}}+\mathrm{DIM} \\
& + \text { herd }+ \text { sire }+\mathrm{e}_{\mathrm{ijk}},
\end{aligned}
$$

where $Y_{\mathrm{ijk}}$ is the phenotype of the kth individual in breed $i$ and parity $j ; \mu$ is the overall trait mean; breed is a fixed effect $(i=1,2,3)$, parity is a fixed effect $(j=1$, $2,3,4)$; and DIM is a covariate of days in milking ( 129 to 229 in DH, d 130 to 252 in DJ, d 18 to 427 in SR). Breed and herd are confounded; therefore, herd is set as a random effect, sire is the random sire effect, and $e_{i j k}$ is the random residual effect. The F statistics for the fixed effects were calculated based on Satterthwaite's approximation for denominator degrees of freedom.

Furthermore, the genetic effects of CSN1S1, CSN2, and CSN3 polymorphisms on CFR and RCT were estimated within breed using the generalized linear mixed model. Because not all casein variants are present in all breeds, different models were used to analyze the effects of the genetic variants on CFR and RCT.

For CSN1S1, the following model was used for $\mathrm{DH}$, DJ, and SR individually:

$$
\begin{aligned}
\mathrm{Y}_{\mathrm{ijk}} & =\mu+\operatorname{herd}_{\mathrm{i}}+\operatorname{parity}_{\mathrm{j}}+\text { DIM } \\
& +C S N 1 S 1+\text { sire }+\mathrm{e}_{\mathrm{ijk}} .
\end{aligned}
$$

For CSN2, the following model was used for $\mathrm{DH}$ :

$$
\begin{aligned}
& \mathrm{Y}_{\mathrm{ijk}}=\mu+\operatorname{herd}_{\mathrm{i}}+\operatorname{parity}_{\mathrm{j}}+\mathrm{DIM}+C S N 2 A^{2} \\
& +C S N 2 A^{3}+C S N 2 B+C S N 2 I+\text { sire }+\mathrm{e}_{\mathrm{ijk}} .
\end{aligned}
$$

For CSN2, the following model was used for DJ:

$$
\begin{aligned}
\mathrm{Y}_{\mathrm{ijk}}= & \mu+\operatorname{herd}_{\mathrm{i}}+\operatorname{parity}_{\mathrm{j}}+\mathrm{DIM}+\text { CSN2A }^{2} \\
& + \text { CSN2B }+ \text { CSN2I }+ \text { sire }+\mathrm{e}_{\mathrm{ijk}} .
\end{aligned}
$$


For CSN2, the following model was used for SR:

$$
\begin{aligned}
\mathrm{Y}_{\mathrm{ijk}} & =\mu+\operatorname{herd}_{\mathrm{i}}+\text { parity }_{\mathrm{j}}+\text { DIM } \\
& +C S N 2 A^{2}+\text { sire }+\mathrm{e}_{\mathrm{ijk}} .
\end{aligned}
$$

For CSN3, the following model was used for $\mathrm{DH}$ and SR:

$$
\begin{aligned}
\mathrm{Y}_{\mathrm{ijk}}=\mu+ & \operatorname{herd}_{\mathrm{i}}+\operatorname{parity}_{\mathrm{j}}+\text { DIM }+ \text { CSN3B } \\
& + \text { CSN3E }+ \text { sire }+\mathrm{e}_{\mathrm{ijk}} .
\end{aligned}
$$

For CSN3, the following model was used for DJ:

$$
\begin{aligned}
\mathrm{Y}_{\mathrm{ijk}}= & \mu+\operatorname{herd}_{\mathrm{i}}+\text { parity }_{\mathrm{j}}+\text { DIM } \\
& + \text { CSN3B }+ \text { sire }+\mathrm{e}_{\mathrm{ijk}},
\end{aligned}
$$

where $Y_{i j k}$ is the phenotype of the kth individual in herd $\mathrm{i}$ and parity $\mathrm{j} ; \mu$ is the overall mean of the trait, herd is a fixed effect $(\mathrm{i}=1,2, \ldots, 22)$; parity is a fixed effect $(\mathrm{j}=1,2,3,4)$; DIM is a covariate of days in milking (d 129 to 229 in DH, d 130 to 252 in DJ, d 18 to 427 in SR); genotype in the model fitted as a covariate is denoted as CSN1S1 C, CSN2 $A^{2}, C S N 2 A^{3}$, CSN2 B, $C S N 2$ I, CSN3 B, or CSN3 $E$ depending on the genotypes present in the population; sire is the random sire effect; and $\mathrm{e}_{\mathrm{ijk}}$ is the random residual effect.

The CN loci are tightly linked on chromosome 6; therefore, composite genotype effects were examined, including composite genotypes with a frequency exceeding $2.5 \%$ within each breed. For testing the effect of a composite genotype, instead of single genotype, the individual composite genotype was fitted as a covariate in the model by using a dummy vector with 0 or 1 , where 0 indicates that the animal does not have the composite genotype and 1 indicates that the animal has the composite genotype. This will give the same result as fitting the composite genotype as a fixed effect with $n$ levels, but allowing a choice of reference genotype; $B B A^{2} A^{2} A A$ was used as the reference CSN1S1-CSN2CSN3 composite genotype.

As the linear mixed models cannot handle rightcensored data such as NC milks, these samples were excluded from data in the prior models. However, to analyze NC milk coagulation traits in SR, the traits were treated as binary (dichotomous), despite the unavoidable information loss related to converting a continuous trait to a binary trait (Cecchinato and Carnier, 2011). In this case, for the SR breed, RCT and CFR coagulating animals were set to 1 and noncoagulating animals were set to 0 , including animals having either one or both coagulation measurements as NC. All models were performed in $\mathrm{R}$ (version 2.15.1; http:// www.r-project.org) using the libraries lme4 and nlme.

Genotypic linkage equilibrium was tested for each pair of loci in each breed using Genepop (version 4.2; http://kimura.univ-montp2.fr/ rousset/Genepop. htm).

\section{RESULTS}

\section{Milk Coagulation}

The number of excluded samples due to high SCC was highest in DH, and even after exclusion of high SCC milk samples, DH and DJ cows still showed higher SCC compared with SR cows. All breeds showed distinct milk composition profiles; however, DH and SR cows generally exhibited higher yields with lower fat and protein percentages (Table 1). Significant influence of breed, parity, and DIM were observed for several traits (Table 2 ). Yield was shown to be highly dependent on parity, with increasing yields in second- and third-parity cows compared with first- and fourth-parity cows. On the other hand, fat and protein percentages were not significantly affected by parity, but increased fat and protein contents were observed with increased DIM.

The 3 breeds showed very different coagulation properties in relation to RCT and CFR (Figure 1, Table 1). For RCT, SR cows generally had longer RCT, which was also reflected in the distribution of RCT, with many samples having extended clotting times compared with DH and DJ, which showed more overlapping distributions. The DJ cows had significantly higher CFR compared with DH and SR cows; in fact, mean CFR was more than twice as high in DJ compared with the other breeds. However, CFR in DH and SR cows was not significantly different in coagulating milk samples, but the number of $\mathrm{NC}$ milk samples varied strongly among breeds, with $65 \mathrm{NC}$ milk samples (NC in 2 coagulation replicates) in SR, 8 in DH, and 0 in DJ. Cows in second and third parity had significantly higher CFR than cows in first and fourth parity, and DIM was positively associated with CFR. Likewise, RCT was significantly influenced by parity and DIM (Table 2).

\section{Allele and Genotype Frequencies of the CN Genes}

For $C S N 1 S 1$, variants $B$ and $C$ were detected in all breeds, whereas CSN1S1 A, D, and $F$ were not found in any of the breeds in this sampling (Table 3 ). The most common CSN1S1 genotypes were $B C$ in DJ and $B B$ in $\mathrm{DH}$ and SR. Five CSN2 variants were resolved in $\mathrm{DH}$ $\left(A^{1}, A^{2}, A^{3}, B\right.$, and $\left.I\right), 4$ variants in DJ (lacking CSN2 $A^{3}$ ), and only 2 variants in SR (CSN2 $A^{1}$ and $A^{2}$ ). Therefore, CSN2 $A^{1} A^{2}$ was the most common genotype 


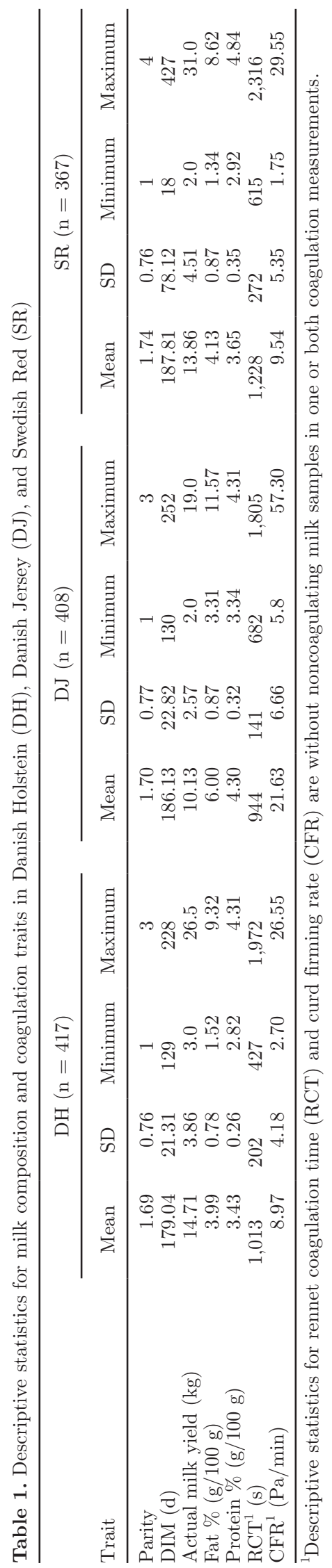

in SR, and CSN2 $A^{2} A^{2}$ was the most common in $\mathrm{DH}$ and DJ (Table 3). Finally, for CSN3, all 3 variants were present in $\mathrm{DH}$ and $\mathrm{SR}$ compared with DJ, in which $C S N 3 E$ was not detected. The CSN3 BB genotype was the most frequent in DJ, and the $A A$ genotype was most frequent in $\mathrm{DH}$ and SR (Table 3). Linkage disequilibrium was detected between all pairs of loci in DJ $(P<0.001)$; between $C S N 1 S 1$ and $C S N 2(P<$ $0.001)$, and $C S N 2$ and $C S N 3(P<0.001)$ in $\mathrm{DH}$; and between CSN1S1 and CSN3 $(P<0.05)$, and CSN2 and $C S N 3(P<0.001)$ in SR. In DJ, the common CSN1S1 $C$ appeared to be strongly associated with CSN2 $A^{2}$ and $C S N 3 B$, as all $C S N 1 S 1 C C$ homozygotes were also homozygotes for CSN2 $A^{2} A^{2}$ and $C S N 3 B B$. In addition, heterozygous $C S N 1 S 1 B C$ always co-occurred with
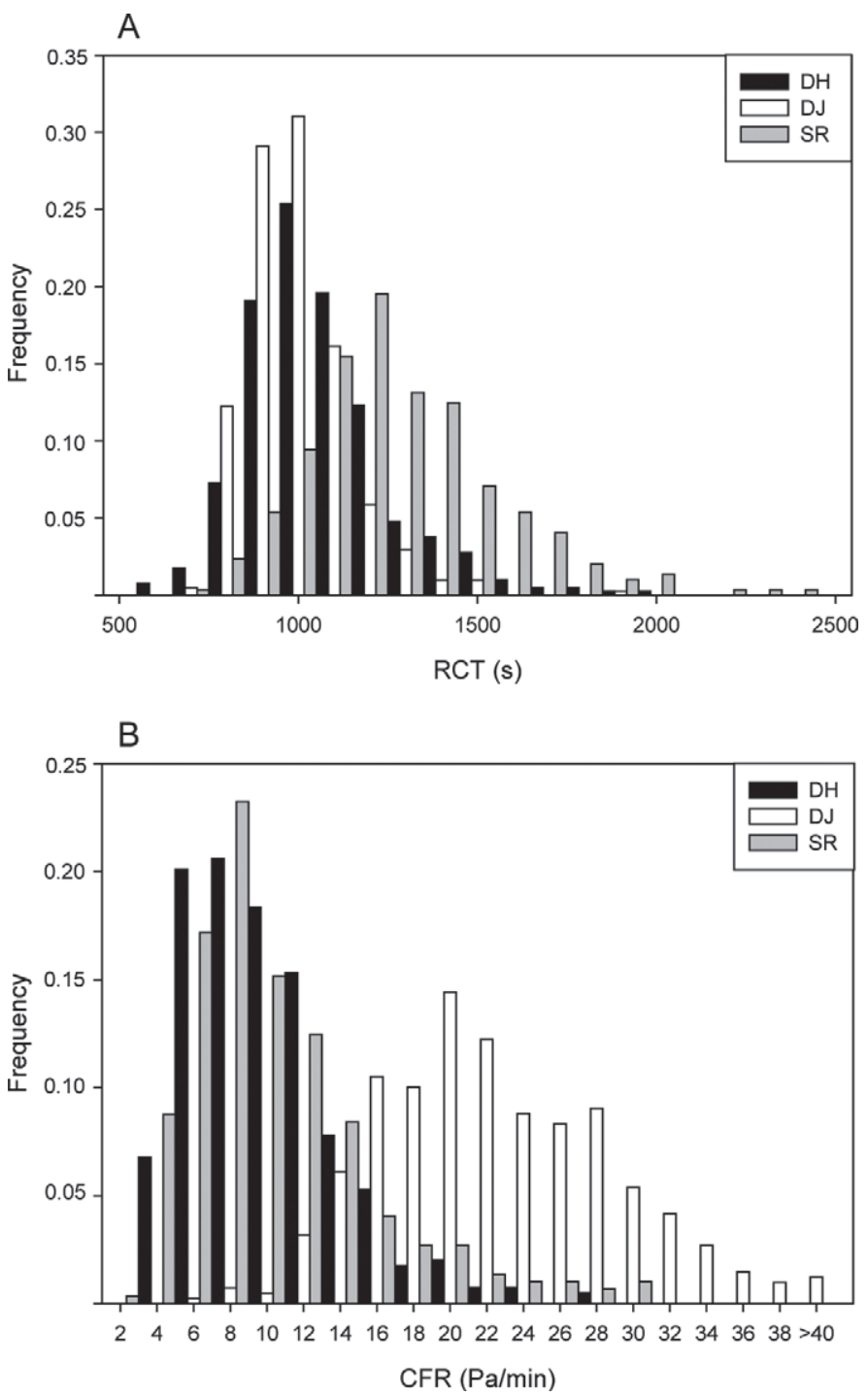

Figure 1. Distribution of (A) rennet coagulation time (RCT) and (B) curd firming rate (CFR) in Danish Holstein (DH), Danish Jersey (DJ), and Swedish Red (SR). 
Table 2. Influence of breed, parity, and DIM on milk composition and coagulation traits in Danish Holstein (DH), Danish Jersey (DJ), and Swedish Red (SR)

\begin{tabular}{lccc}
\hline Trait $^{1}$ & Breed & Parity & DIM \\
\hline SCC $(\times 1,000$ cells $/ \mathrm{mL})$ & $* * *$ & $* * *$ & $* * *$ \\
Actual milk yield $(\mathrm{kg})$ & $* * *$ & $* * *$ & $* * *$ \\
Fat percentage $(\mathrm{g} / 100 \mathrm{~g})$ & $* * *$ & $\mathrm{NS}$ & $* * *$ \\
Protein percentage $(\mathrm{g} / 100 \mathrm{~g})$ & $* * *$ & $\mathrm{NS}$ & $* * *$ \\
$\mathrm{RCT}(\mathrm{s})$ & $* * *$ & $* * *$ & $*$ \\
$\mathrm{CFR}(\mathrm{Pa} / \mathrm{min})$ & $* * *$ & $* * *$ & $* * *$ \\
\hline
\end{tabular}

${ }^{1} \mathrm{RCT}=$ rennet coagulation time; $\mathrm{CFR}=$ curd firming rate.

${ }^{*} P<0.05 ;{ }^{* *} P<0.01 ;{ }^{* * *} P<0.001 ;$ NS: $P>0.05$.

CSN2 $A^{2}$ and CSN3 $B$ in DJ and SR, which were not detected in DH. Similarly, strong genetic associations were observed for CSN2 $A^{1}$ and $C S N 3 E$ and between CSN2 I and CSN3 B. The high number of NC samples in SR showed a similar variant distribution relative to the total SR sample population, but a tendency was observed toward higher frequencies of CSN2 $A^{2}$ and CSN3 $A$ and CSN3 E (Table 3 ).

The numbers of CSN1S1-CSN2-CSN3 composite genotypes were 27 in $\mathrm{DH}, 17$ in DJ, and 16 in SR. As reflected in the variant differences among breeds, the prevalence and frequency of the composite genotypes varied among breeds. A total of 19 composite genotypes represented 87 to $97 \%$ of the genotyped animals in $\mathrm{DH}$, DJ, and SR (Table 4). The most common composite genotypes were $B B A^{2} A^{2} A A$ in $\mathrm{DH}, B C A^{2} A^{2} A B$ in DJ, and $B B A^{1} A^{2} A E$ in SR (Table 4). Composite genotypes observed in less than $2.5 \%$ of the cows within each breed were discarded from the statistical analyses.

\section{Influence of CN Genes on Milk Coagulation Traits}

The effect of the genetic $\mathrm{CN}$ variants showed that several of them significantly affected RCT and CFR. The effects of the individual genetic variants within each breed and CN gene are provided in Table 5. The results observed for CSN1S1 resolved a significant effect of CSN1S1 $C$ in DJ, where CSN1S1 $C$ was associated with significantly higher CFR and shorter RCT than CSN1S1 $B$. For CSN2, CSN2 $A^{2}$ showed significantly longer RCT in DH and SR, and a significantly lower CFR in DH and DJ compared with CSN2 $A^{1}$. Furthermore, CSN2 B was associated with significantly shorter RCT and significantly higher CFR in DH, and CSN2 I was associated with significantly longer RCT in $\mathrm{DH}$, and significantly lower CFR in DJ compared with CSN2 $A^{1}$. Relative to $C S N 3$ A, CSN3 $B$ was associated with significantly shorter RCT in DH and DJ, and higher CFR in all 3 breeds; however, no significant effects were observed for CSN3 E. Noncoagulating and coagulating milk samples in SR were analyzed as a binomial traits, and results confirmed that CSN2 $A^{2}$ was significantly associated with lower CFR and longer RCT (data not shown).

Table 3. Genotype and allele frequencies of CSN1S1, CSN3, and CSN2 in 417 Danish Holstein (DH), 408 Danish Jersey (DJ), and 367 Swedish Red (SR) cows

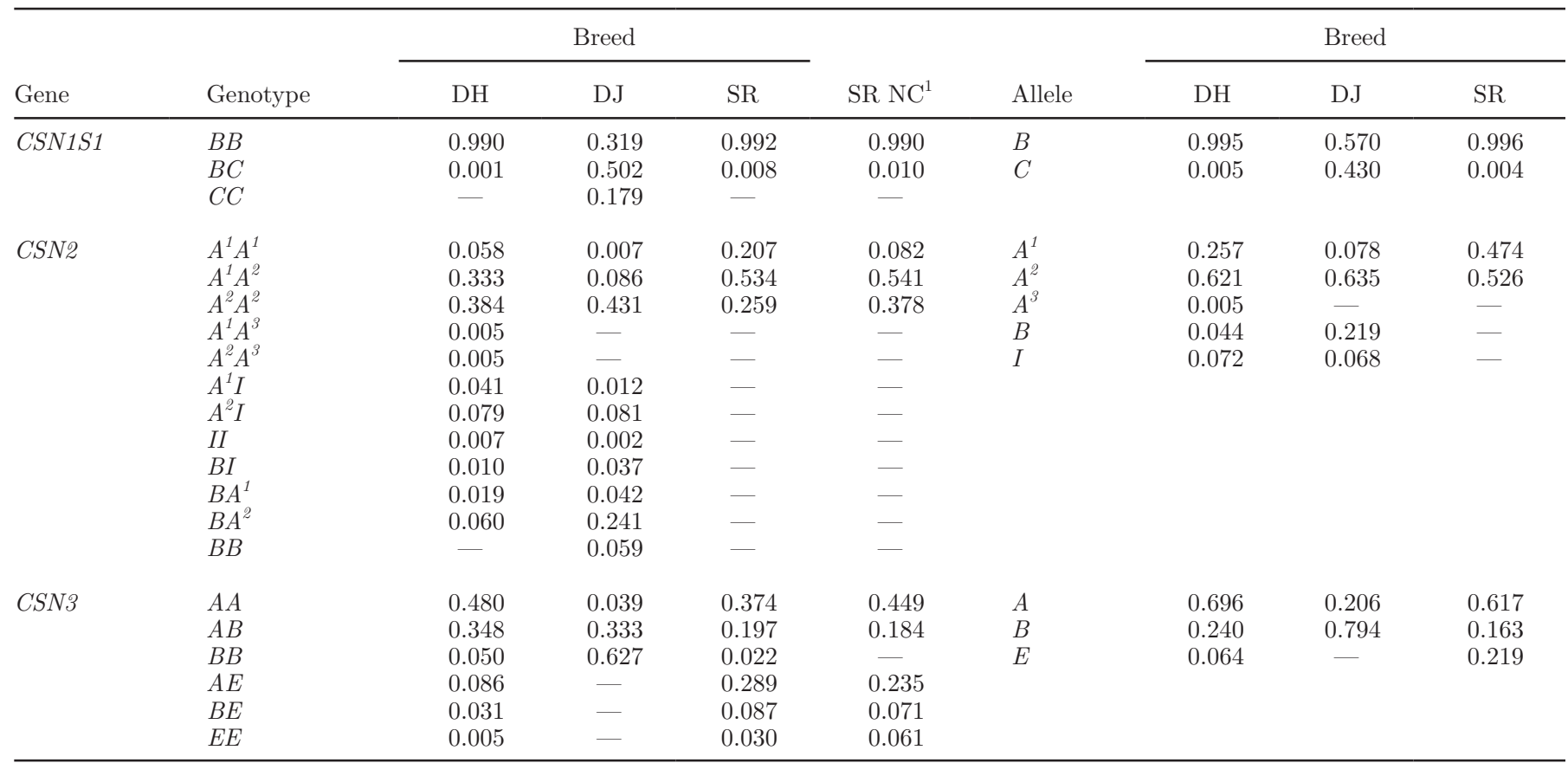

${ }^{1}$ Frequency of cows with a specific genotype within the SR cow group producing noncoagulating (NC) milks in one or both rheological measurements. 
Table 4. Frequencies of the most common CSN1S1-CSN2-CSN3 composite genotypes in Danish Holstein (DH), Danish Jersey (DJ), and Swedish Red (SR) cows

\begin{tabular}{lccc}
\hline & \multicolumn{3}{c}{ Breed } \\
\cline { 2 - 4 } Casein & DH & SR & DJ \\
\hline genotype & $0.295^{2}$ & $0.150^{2}$ & $0.039^{2}$ \\
$B B A^{2} A^{2} A A$ & $0.084^{2}$ & $0.076^{2}$ & 0.022 \\
$B B A^{1} A^{2} A B$ & $0.161^{2}$ & $0.174^{2}$ & - \\
$B B A^{1} A^{2} A A$ & $0.077^{2}$ & $0.188^{2}$ & - \\
$B B A^{1} A^{2} A E$ & 0.010 & $0.098^{2}$ & - \\
$B B A^{1} A^{1} A E$ & 0.010 & $0.074^{2}$ & - \\
$B B A^{1} A^{2} B E$ & $0.086^{2}$ & $0.095^{2}$ & - \\
$B B A^{2} A^{2} A B$ & 0.017 & $0.049^{2}$ & - \\
$B B A^{1} A^{1} A A$ & 0.005 & $0.030^{2}$ & - \\
$B B A^{1} A^{1} E E$ & - & 0.005 & $0.213^{2}$ \\
$B C A^{2} A^{2} A B$ & $0.067^{2}$ & - & $0.029^{2}$ \\
$B B A^{2} I A B$ & $0.050^{2}$ & - & $0.066^{2}$ \\
$B B B A^{2} A B$ & 0.010 & - & $0.034^{2}$ \\
$B B B I B B$ & - & - & $0.042^{2}$ \\
$B B B A^{1} B B$ & - & - & $0.174^{2}$ \\
$B C B A^{2} B B$ & - & - & $0.176^{2}$ \\
$C C A^{2} A^{2} B B$ & - & - & $0.051^{2}$ \\
$B C A^{2} I B B$ & - & - & $0.061^{2}$ \\
$B C A^{1} A^{2} B B$ & - & - & $0.059^{2}$ \\
$B B B B B B$ & - & 0.060 & 0.032 \\
Other & 0.132 &
\end{tabular}

${ }^{1}$ Other refers to remaining samples not having the most common composite genotypes.

${ }^{2}$ Composite genotypes included in the statistical model (frequency $>2.5 \%$ ).

The most common composite genotypes were examined using a model similar to that applied for the individual genes, and the results indicated that several genotypes significantly affected RCT and CFR (Figure $2)$. In all breeds, the composite genotype $B B A^{2} A^{2} A A$ was consistently associated with suboptimal coagulation properties, and animals having this genotype typically exhibited long RCT and low CFR. In DH in particular, heterozygous cows with CSN3 $B$ had significantly higher CFR than cows homozygous for CSN3 $A$. This was not true for cows with CSN2 I, which had significantly longer RCT and lower CFR as the reference irrespective of being heterozygous for CSN3 $B$. Furthermore, cows with $C S N 3 E$ had significantly lower CFR relative to $B B A^{2} A^{2} A A$. An effect of $C S N 3$ $B$ on RCT in SR was not evident; however, cows heterozygous for CSN3 B generally had higher CFR. The observed pattern for SR was primarily driven by CSN2 genotypes: cows homozygous for CSN2 $A^{1}$ showed superior CFR except when also homozygous for CSN3 E. Danish Jersey cows homozygous for CSN3 B exhibited superior coagulation properties, particularly in combination with $C S N 1 S 1 C$, resulting in significantly higher $\mathrm{CFR}$ and shorter RCT. However, this was not evident in cows with CSN2 I.

\section{DISCUSSION}

\section{Effect of Breed on Milk Composition and Milk Coagulation}

In this study, milk coagulation was examined through 2 traits, RCT and CFR. Rennet coagulation time measures initial micelle aggregation, when approximately $85 \%$ of $\kappa-\mathrm{CN}$ is hydrolyzed (Fox and McSweeney, 1998). Viscosity in the sample cup changes, which leads to a

Table 5. Least squares estimates $( \pm \mathrm{SE})$ of the effect of casein variants within each breed ${ }^{1}$

\begin{tabular}{|c|c|c|c|c|}
\hline Trait & Allele & Danish Holstein & Danish Jersey & Swedish Red \\
\hline \multirow[t]{10}{*}{$\mathrm{RCT}$} & $C S N 1 S 1 B$ & $1,072.27 \pm 112.62$ & $1,049.55 \pm 84.49$ & $1,427.82 \pm 70.53$ \\
\hline & CSN1S1C & $1,028.02 \pm 101.49$ & $1,024.85 \pm 10.84^{*}$ & $1,092.08 \pm 204.69$ \\
\hline & CSN3 A & $1,095.44 \pm 109.45$ & $1,163.43 \pm 83.86$ & $1,428.81 \pm 72.44$ \\
\hline & CSN3 B & $1,016.67 \pm 16.75^{* * *}$ & $1,089.31 \pm 12.56^{* * *}$ & $1,389.36 \pm 34.57$ \\
\hline & CSN3 $E$ & $1,059.97 \pm 27.69$ & - & $1,423.50 \pm 34.29$ \\
\hline & CSN2 $A^{1}$ & $977.38 \pm 111.96$ & $1,040.84 \pm 89.67$ & $1,324.69 \pm 77.92$ \\
\hline & $C S N 2 A^{2}$ & $1,040.41 \pm 16.28^{* * *}$ & $1,053.84 \pm 18.40$ & $1,387.66 \pm 26.17^{*}$ \\
\hline & $C S N 2 A^{3}$ & $974.14 \pm 95.77$ & - & - \\
\hline & CSN2 B & $882.67 \pm 35.18^{* *}$ & $998.95 \pm 21.32$ & - \\
\hline & CSN2 I & $1,036.97 \pm 28.89 *$ & $1,084.18 \pm 25.82$ & - \\
\hline \multirow[t]{10}{*}{ CFR } & CSN1S1 B & $2.81 \pm 2.36$ & $12.88 \pm 3.28$ & $2.04 \pm 1.17$ \\
\hline & CSN1S1C & $1.62 \pm 2.33$ & $14.39 \pm 0.42^{* * *}$ & $11.17 \pm 3.68^{*}$ \\
\hline & CSN3 A & $1.36 \pm 2.13$ & $7.28 \pm 3.07$ & $2.15 \pm 1.18$ \\
\hline & $C S N 3 B$ & $4.38 \pm 0.33^{* * *}$ & $11.71 \pm 0.47^{* * *}$ & $3.98 \pm 0.58^{* *}$ \\
\hline & CSN3 E & $1.21 \pm 0.54$ & & $1.12 \pm 0.54$ \\
\hline & $C S N 2 A^{1}$ & $5.12 \pm 2.33$ & $18.11 \pm 3.56$ & $3.54 \pm 1.30$ \\
\hline & $C S N 2 A^{2}$ & $3.77 \pm 0.34^{* * *}$ & $15.79 \pm 0.77^{* *}$ & $2.71 \pm 0.44$ \\
\hline & $C S N 2 A^{3}$ & $3.14 \pm 2.17$ & $10.19 \pm 0.11$ & $2.11 \pm 0.40$ \\
\hline & $C S N 2 B$ & $6.92 \pm 0.75^{*}$ & $17.22 \pm 0.85$ & - \\
\hline & CSN2 I & $5.77 \pm 0.62$ & $15.43 \pm 1.08^{*}$ & - \\
\hline
\end{tabular}

${ }^{1}$ Significance level is shown for the effect of CSN1S1 $C$ compared with CSN1S1 B, CSN3 $B$ and CSN3 $E$ compared with CSN3 $A$, and CSN2 $A^{2}, C S N 2 A^{3}, C S N 2$ 2 , and CSN2 I compared with CSN2 $A^{1}$ for rennet coagulation time (RCT) and curd firming rate (CFR).

${ }^{*} P<0.05 ; * * P<0.01 ;{ }^{* * *} P<0.001$. 
rapid damping of the oscillations. Subsequently, gel formation takes place through further aggregation, resulting in an increasing gelation curve as the strength of the gel increases. Curd firming rate is therefore highly correlated with the maximum gel strength achieved, whereas the relationship between RCT and CFR is more complex and varies among breeds (Frederiksen et al., 2011b). Poor coagulation is generally associated with low CFR and long RCT, even though the correlation between traits is not always strong and samples with long RCT can exhibit a considerable CFR (Wedholm et al., 2006).

Milk storage is known to affect milk coagulation (Larsen et al., 1996), and the 24-h storage period before the SR milk coagulation measurements in the present study could have affected coagulation properties of stored samples. However, comparable coagulation measurements conducted on fresh SR milk samples, immediately following collection, using low amplitude oscillation measurements (Stresstech rheometer, ReoLogica Instruments AB, Lund, Sweden) confirmed that the coagulation properties of individual milk samples from the 2 different rheometry-based methods (Stresstech and ReoRox) on fresh and cold-stored milk, respectively, were highly correlated (data not shown). The results indicated that inferior SR coagulation was not strongly affected by storage period, but rather was a result of breed-related differences in milk composition. Furthermore, high SCC milk samples indicative of subclinical or clinical mastitis and subsequent impaired milk coagulation were excluded to ensure that breed effect was not merely reflecting differences in health status among breeds or other factors that impair raw milk quality. Similarly, the rheological analysis was conducted on skim milk samples that were $\mathrm{pH}$ adjusted before measurements. Therefore, potential $\mathrm{pH}$-dependent differences in chymosin action on ${ }^{-} \mathrm{CN}$ in the first phase of the milk coagulation process were eliminated, and coagulation properties primarily reflected differences in the secondary phase. Negatively charged groups were partially neutralized by $\mathrm{pH}$ adjustments, and this was formerly shown to primarily affect RCT, and not the effect of CSN3 variants on CFR (Schaar, 1984).

Superior coagulation properties in DJ cows were largely reflected in higher CFR compared with DH and $\mathrm{SR}$, in addition to the absence of $\mathrm{NC}$ samples. Apart from milk coagulation traits, the 3 breeds showed distinct overall milk composition, and milk from DJ cows exhibited higher protein and fat percentages compared with DH and SR. The higher protein percentage in DJ cows could be largely responsible for the better coagulation observed in DJ. However, similar protein percentages in SR and DH suggested that coagulation was not affected by protein alone, congruent with Frederiksen et al. (2011b), showing that CFR could not be determined solely by protein percentage in DJ and DH.

Compared with other modern European dairy cattle breeds, DJ cows have superior coagulation properties, but also a lower milk yield (Frederiksen et al., 2011b; Poulsen et al., 2012). The frequency of NC milk samples observed in DH was lower than in other European Holstein populations (Cassandro et al., 2008; Jõudu et al., 2008), and notably lower than the observed $16 \%$ NC milks in SR cows. However, it is important to emphasize that no formal definition of $\mathrm{NC}$ milk exists, and different studies have been conducted using different rheological methods with different pretreatments and rennet concentrations. Despite this, the prevalence of NC milk was higher in SR than in other Scandinavian breeds, including Finnish Ayrshire and Estonian native cattle (Ikonen et al., 2004; Tyrisevä et al., 2004; Jõudu et al., 2007). Therefore, a substantial proportion of cows produce raw milk unsuitable for cheese production, and the severe coagulation problems in the SR breeding population are certainly not desirable for dairies. Gradually blending NC milk with well-coagulating milk compromises the well-coagulating milk in a manner similar to titration (Frederiksen et al., 2011a), and addition of calcium chloride is required to restore the milk for cheese production (Hallén et al., 2010).

In NC milk, the enzymatic coagulation phase does not seem impaired, as NC samples and those with poor and good coagulation properties have been shown to have the same caseinomacropeptide content after rennet-induced coagulation (Frederiksen et al., 2011a). However, noncoagulation and poor coagulation could be associated with lower $\kappa$-CN content and larger $\mathrm{CN}$ micelles (Hallén et al., 2010; Frederiksen et al., 2011a), as smaller micelles aggregate faster and form firmer gels (Glantz et al., 2010). Furthermore, the aggregation phase seems to be influenced by the degree of phosphorylation, as the most phosphorylated $\alpha_{\mathrm{S}^{-}}$and $\alpha_{\mathrm{S}_{2}} \mathrm{CN}$ forms are associated with $\mathrm{NC}$ and poor coagulation (Frederiksen et al., 2011a; Jensen et al., 2012b), suggesting the higher negative net charge of the CN impairs micellar aggregation, and thereby coagulation (Feagan et al., 1972).

\section{Genetic Polymorphism of CN Genes}

Numerous genetic variants have been identified within Bos taurus; however, most are present at low frequency in common dairy breeds (Farrell et al., 2004; Caroli et al., 2009). For most animals in the current study, the Taqman assay was successful in genotyping all the common CSN1S1, CSN2, and CSN3 variants. It 


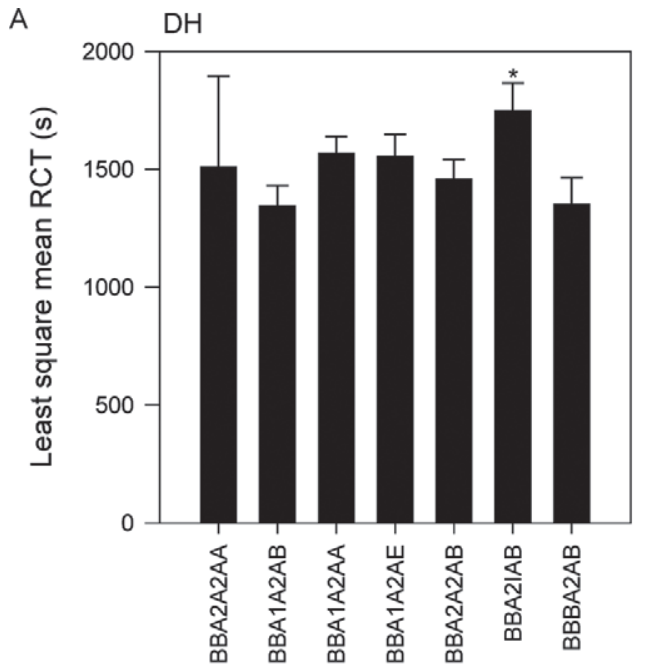

B
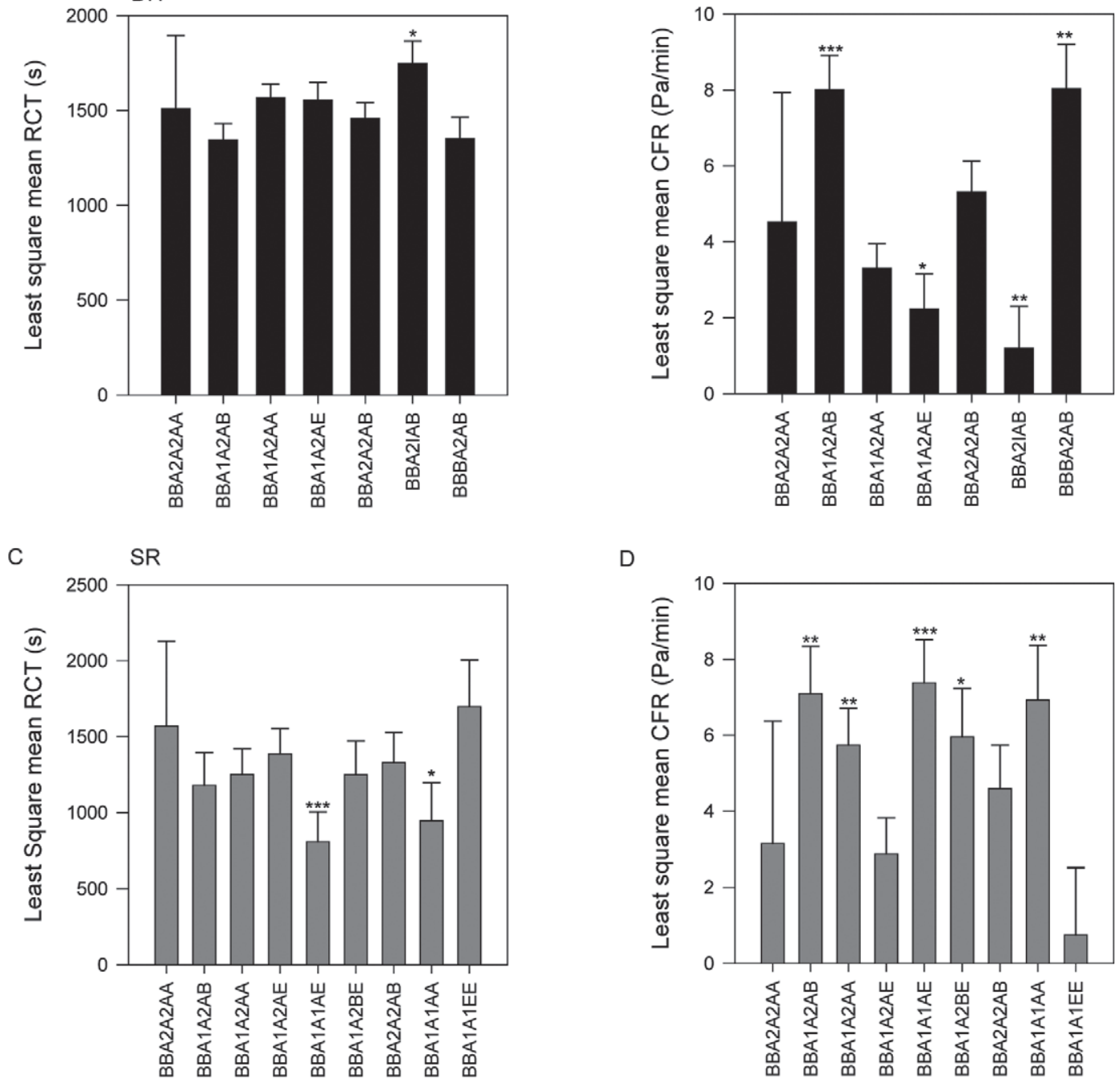

D

$\mathrm{E}$

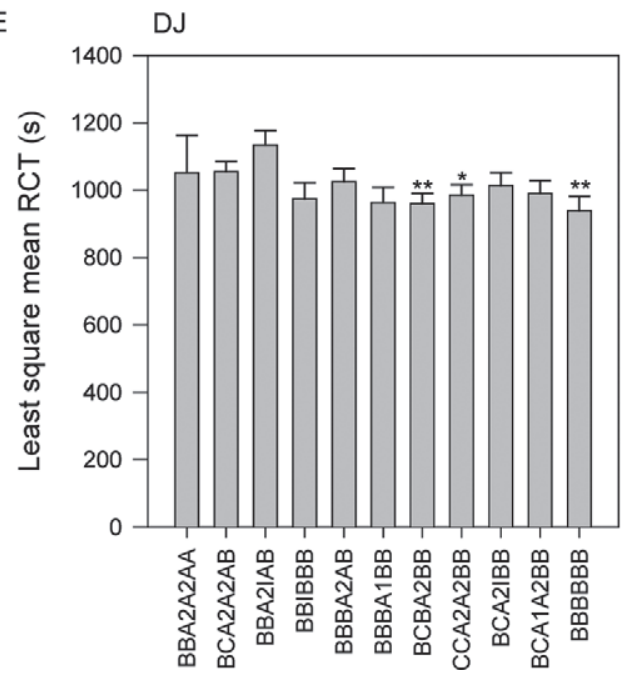

$\mathrm{F}$

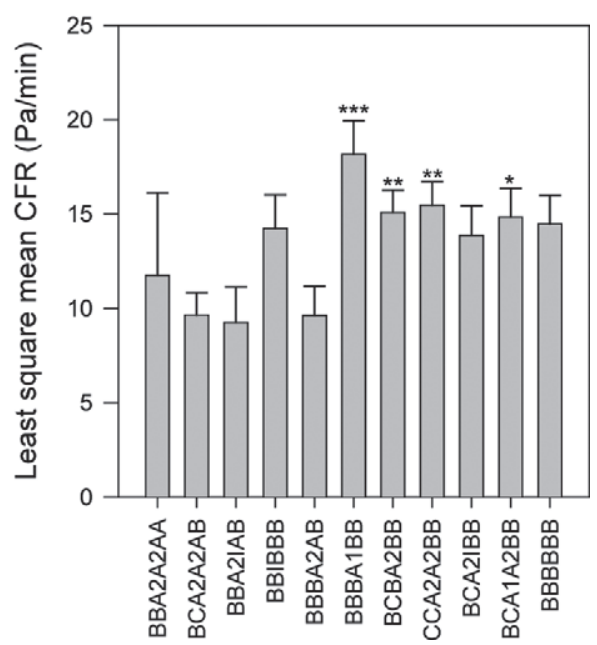

Figure 2. Least squares estimates with standard errors of the effect of the most common composite genotypes on rennet coagulation time (RCT) and curd firming rate (CFR) for Danish Holstein (DH; panels A and B), Swedish Red (SR; panels C and D) and Danish Jersey (DJ; panels $\mathrm{E}$ and $\mathrm{F}$ ). Significance is indicated for the effect of different $C S N 1 S 1-C S N 2-C S N 3$ composite genotypes compared with $B B A^{2} A^{2} A A .{ }^{*} P$ $<0.05,{ }^{* *} P<0.01,{ }^{* * *} P<0.001$. 
is important, however, to emphasize that a recombination event between screening sites, potentially resulting in new genetic variants, could not be identified with our experimental design. Cows heterozygous at more than one screening site could therefore have been falsely assigned to the known variants. However, the probability that recombination could have affected correct genotyping is mainly speculative and all heterozygous genotypes were included in the data.

The characteristics of the different breeds are consistent with previous reports showing high frequencies of CSN1S1 C, CSN2 B, and CSN3 B in DJ (Bech and Kristiansen, 1990; Lien et al., 1999), low CSN2 $A^{3}$ frequencies in all breeds, and a relatively high CSN3 $E$ frequency in SR (Lien et al., 1999; Hallén et al., 2008). However, the relatively high CSN2 I frequency in both $\mathrm{DH}$ and DJ has not previously been documented. The CSN2 I variant was identified recently, but frequencies ranging from 0.05 to 0.14 in European cattle breeds suggest that the origin of the variant is reasonably old (Jann et al., 2002; Bonfatti et al., 2010b). In most studies, CSN2 I has not been discriminated from CSN2 $A^{2}$ because the amino acid exchange characterizing these variants $\left(\right.$ Met $^{93} \rightarrow$ Leu) does not change the charge of the protein, and the widely used electrophoretic techniques require coupling to mass spectrometry to discriminate $\beta$-CN protein variant $I$ from $A^{2}$ (Jensen et al., 2012a,b) or appropriate optimization of liquid chromatographic methods (Bonfatti et al., 2008, 2010b). Thus, in a large screening study of Dutch Holstein cows, $\beta$-CN protein variant $I$ was not recognized by capillary zone electrophoresis (Heck et al., 2008, 2009), but DNA markers subsequently resolved a relatively high frequency (0.192) using the same samples (Visker et al., 2011).

The genomic organization of the 4 closely linked CN loci on chromosome 6 is CSN1S1-CSN2-CSN1S2CSN3 (Threadgill and Womack, 1990). Therefore, CN gene polymorphisms were examined separately and as composite genotypes. Congruent with our results, linkage disequilibrium between the CSN2 and CSN3 variants was formerly reported in several breeds (Ojala et al., 1997; Ikonen et al., 1999a; Jõudu et al., 2007) and between CSN1S1 and CSN2 in Jersey cows (Van Eenennaam and Medrano, 1991). The strong genetic associations between CSN2-CSN3 $I B$ and $A^{1} E$ found previously (Visker et al., 2011) were also confirmed in the present study. Linkage disequilibrium between CN genes clearly biases the effect of individual alleles on milk coagulation properties. However, because DH, DJ, and SR exhibited very different composite genotype distributions, single gene effects were also reported.

\section{CN Polymorphisms and the Effects on Milk Coagulation}

The effects of CN genetic variants on milk coagulation traits have strong support (see reviews by Jakob and Puhan, 1992; Buchberger and Dovc, 2000; Caroli et al., 2009; Bittante et al., 2012). In the present study, a large number of cows were genotyped for the most common CN variants in 3 Scandinavian breeds, which showed marked differences in milk composition as well as genetic background. The beneficial effects of $C S N 3 B$ on milk coagulation traits observed here has been well established (Schaar, 1984; Ikonen et al., 1999a; Hallén et al., 2007, 2008) and is likely related to higher $\kappa-\mathrm{CN}$ content (Mayer et al., 1997). In SR, the effect was not significant, probably because of the lower frequency of CSN3 $B$ and increased NC prevalence, which reduced the sample size used in the estimates. However, a tendency toward the same pattern was evident. On the other hand, it was expected $C S N 3 E$ would be associated with poor coagulation (Ikonen et al., 1999a; Hallén et al., 2007), which was not observed, even though $E$ variant frequency was higher in $\mathrm{NC}$ cows. The CSN3 E variant is thought to have its origin in Finnish Ayrshire (Lien et al., 1999), and a close genetic relationship between SR and Ayrshire is also reflected in both breeds having high NC prevalence and relatively high CSN3 E frequencies (Ikonen et al., 1999a; Tyrisevä et al., 2004). Other candidate genes thought to be involved in NC include genes influencing glycosylation of $\kappa$-CN (Tyrisevä et al., 2008).

The positive effect of CSN1S1 C observed in DJ was evident in shorter RCT and higher CFR compared with CSN1S1 B; CSN1S1 $C$ is present at low frequency in many commonly studied breeds. However, CSN1S1 C was associated with good coagulation in earlier studies as well (Oloffs et al., 1992; Ikonen et al., 1999a; Jõudu et al., 2007). For CSN2, the most pronounced effect observed was the negative influence of $A^{2}$ on milk coagulation compared with $A^{1}$, which was significant for CFR in all breeds and for RCT in DH and SR. Other studies have associated CSN2 $A^{2} A^{2}$ with poor coagulation (Hallén et al., 2007), whereas $C S N 2 A^{1} A^{2}$ and $A^{1} A^{1}$ have been related to good coagulation (Ikonen et al., 1997, 1999a) and increased cheese yields (Marziali and Ng-Kwai-Hang, 1986). The positive association between CSN2 B and milk coagulation was only observed in $\mathrm{DH}$, despite the highest frequency of the variant in DJ. Interestingly, CSN2 I also seemed to influence coagulation traits in $\mathrm{DH}$ and $\mathrm{DJ}$, but resulted in poor coagulation with longer RCT in DH relative to $A^{1}$, and lower CFR in DJ. Visker et al. (2011) showed a higher protein percentage and protein and casein yields associ- 
ated with CSN2 I. Therefore, we expected a positive effect of CSN2 I on coagulation traits, but the close similarity of CSN2 I and CSN2 $A^{2}$ might also play a role, resulting in the association with poor coagulation.

Composite genotypes effects could largely be explained by individual genotypes, including $C S N 3 B$. Improved coagulation properties in CSN2-CSN3 composite genotypes containing at least one $B$ variant in both loci have been reported in Italian Holstein and Simmental cows (Comin et al., 2008; Bonfatti et al., 2010a). This effect is probably related to protein composition, and Bonfatti et al. (2010b) found CSN2 B and CSN3 B haplotypes were related to increased $\mathrm{CN}$ content and CN number in Simmental cows, and haplotypes carrying $C S N 3$ B demonstrated increased $\kappa$-CN content and percentage of $\kappa-\mathrm{CN}$ to total CN. In our study, DJ cows exhibited a high frequency of the $C S N 3 B$ variant, and results showed that composite genotypes with $C S N 3$ $B B$ were superior compared with composite genotypes with $A A$ and $A B$ genotypes, whereas in $\mathrm{DH}$, composite genotypes with $C S N 3 A B$ were generally superior to those with CSN3 AA. Swedish Red exhibited similar results, although the association with CSN 3 and coagulation properties was not as clear. However, in DH, composite genotype $B B A^{2} I A B$ did not show improved coagulation properties, and the positive association of CSN2-CSN3 IB haplotypes with protein percentage found in Dutch Holstein-Friesian (Visker et al., 2010) and Italian Simmental cows (Bonfatti et al., 2010b) cannot be reflected in improved coagulation properties here. Results from Bonfatti et al. (2010a) suggested an unfavorable effect of haplotypes containing CSN2 I on CFR when associated with CSN3 A, which might explain the difference in the results reported. The positive association of CSN1S1 C with milk coagulation in DJ cows did not seem to solely drive the association in the composite genotypes but was highly dependent on the genetic association to CSN3 variants. Therefore, the marked association of CSN2 $A^{2}$ with poor milk coagulation is evidently more complex due to the suggested $A^{2}$ linkage with favorable CSN1S1 and CSN3 variants.

Increasing the frequency of unfavorable coagulation variants is undesirable, and improved coagulation is an important breeding goal to enhance cheese milk quality. Genetic improvement of coagulation properties seems possible based on estimated heritabilities for coagulation traits, within a range of 0.15 to 0.40 (Ikonen et al., 1999a; Cassandro et al., 2008). Furthermore, future studies addressing the complex relationships between milk coagulation and factors affecting the physicochemical properties of the casein micelles will provide important knowledge regarding various aspects including the content of different proteins, posttranslational modifications, and minerals, among others.

\section{CONCLUSIONS}

This study provides evidence of breed differences in relation to coagulation properties in major Scandinavian dairy breeds. The high NC milk prevalence in SR cows is a serious concern, and may result in impaired raw milk quality delivered to dairies, which has potential to lower overall cheese yield. Our results showed that genetic variation of casein genes was highly associated with coagulation properties, suggesting that milk coagulation is under genetic influence. Generally, good coagulation was associated with $C S N 1 S 1 C$ and $C S N 3$ $B$, whereas poor coagulation was associated with CSN2 $A^{2}$ and CSN2 I. The positive effects of CSN3 $B$ on milk coagulation properties have been well documented and are presumably related to higher $\kappa-\mathrm{CN}$ content and smaller micelles.

\section{ACKNOWLEDGMENTS}

Arla Foods amba (Viby J, Denmark), The Danish Cattle Federation (Aarhus N, Denmark), the Danish Strategic Research Council (Copenhagen K, Denmark), Aarhus University (Aarhus, Denmark), the Milk Levy Fund ( Aarhus N, Denmark), and the Swedish Farmers' Foundation for Agricultural Research (SLF; Stockholm, Sweden).The Danish sampling and analysis team at the Danish-Swedish Milk Genomics Initiative are gratefully acknowledged for their excellent technical assistance.

\section{REFERENCES}

Bech, A.-M., and K. R. Kristiansen. 1990. Milk protein polymorphism in Danish dairy cattle and the influence of genetic variants on milk yield. J. Dairy Res. 57:53-62.

Bittante, G., M. Penasa, and A. Cecchinato. 2012. Invited review: Genetics and modeling of milk coagulation properties. J. Dairy Sci. 95:6843-6870.

Bonfatti, V., G. Di Martino, A. Cecchinato, L. Degano, and P. Carnier. 2010a. Effects of $\beta$-к-casein (CSN2-CSN3) haplotypes, $\beta$-lactoglobulin $(B L G)$ genotypes, and detailed protein composition on coagulation properties of individual milk of Simmental cows. J. Dairy Sci. 93:3809-3817.

Bonfatti, V., G. Di Martino, A. Cecchinato, D. Vicario, and P. Carnier. 2010b. Effects of $\beta$-к-casein (CSN2-CSN3) haplotypes, $\beta$-lactoglobulin $(B L G)$ genotypes on milk production traits and detailed protein composition of individual milk of Simmental cows. J. Dairy Sci. 93:3797-3808.

Bonfatti, V., L. Grigoletto, A. Cecchinato, L. Gallo, and P. Carnier. 2008. Validation of a new reversed-phase high-performance liquid chromatography method for separation and identification of bovine milk protein genetic variants. J. Chromatogr. A 1195:101-106.

Buchberger, J., and P. Dovc. 2000. Lactoprotein genetic variants in cattle and cheese making ability. Food Technol. Biotechnol. 38:91-98.

Caroli, A. M., S. Chessa, and G. J. Erhardt. 2009. Invited review: Milk protein polymorphisms in cattle: Effect on animal breeding and human nutrition. J. Dairy Sci. 92:5335-5352.

Cassandro, M., A. Comin, M. Ojala, R. Dal Zotto, M. De Marchi, L. Gallo, P. Carnier, and B. Bittante. 2008. Genetic parameters of milk coagulation properties and their relationships with milk 
yield and quality traits in Italian Holstein cows. J. Dairy Sci. 91:371-376.

Cecchinato, A., and P. Carnier. 2011. Short communication: Statistical models for the analysis of coagulation traits using coagulation and noncoagulating milk information. J. Dairy Sci. 94:4214-4219.

Comin, A., M. Cassandro, S. Chessa, M. Ojala, R. Dal Zotto, M. De Marchi, P. Carnier, L. Gallo, G. Pagnacco, and G. Bittante. 2008. Effects of composite $\beta$ - and $\kappa$-casein genotypes on milk coagulation, quality, and yield traits in Italian Holstein cows. J. Dairy Sci. 91:4022-4027.

De Marchi, M., R. Dal Zotto, M. Cassandro, and G. Bittante. 2007. Milk coagulation ability of five dairy cattle breeds. J. Dairy Sci. 90:3986-3992.

Farrell, H. M., Jr., R. Jimenez-Flores, G. T. Bleck, E. M. Brown, J. E. Butler, L. K. Creamer, C. L. Hicks, C. M. Hollar, K. F. Ng-KwaiHang, and H. E. Swaisgood. 2004. Nomenclature of the proteins of cows' milk — Sixth revision. J. Dairy Sci. 87:1641-1674.

Feagan, J. T., L. F. Bailay, A. F. Hehir, D. M. McLean, and N. J. S. Ellis. 1972. Coagulation of milk proteins. I. Effect of genetic variants of milk proteins on rennet coagulation and heat stability of normal milk. Aust. J. Dairy Technol. 27:129-134.

Fox, P. F., and P. L. H. McSweeney. 1998. Dairy Chemistry and Biochemistry. Blackie Academic and Professional, London, UK.

Frederiksen, P. D., K. K. Andersen, M. Hammershøj, H. D. Poulsen, J. Sørensen, M. Bakman, K. B. Qvist, and L. B. Larsen. 2011a. Composition and effect of blending of noncoagulating, poorly coagulating and well-coagulating bovine milk from individual Danish Holstein cows. J. Dairy Sci. 94:4787-4799.

Frederiksen, P. D., M. Hammershøj, M. Bakman, P. N. Andersen, J. B. Andersen, K. B. Qvist, and L. B. Larsen. 2011b. Variations in coagulation properties of cheese milk from three Danish dairy breeds as determined by a new free oscillation rheometry-based method. Dairy Sci. Technol. 91:309-321.

Glantz, M., A. Håkansson, H. Lindmark Månsson, M. Paulsson, and L. Nilsson. 2010. Revealing the size, conformation, and shape of casein micelles and aggregates with asymmetrical flow field-flow fractionation and multiangle light scattering. Langmuir 26:12585-12591.

Green, M. L., and S. V. Morant. 1981. Mechanism of aggregation of casein micelles in rennet-treated milk. J. Dairy Res. 48:57-63.

Hallén, E., T. Allmere, J. Näslund, A. Andrén, and A. Lundén. 2007. Effect of genetic polymorphism of milk proteins on rheology of chymosin-induced milk gels. Int. Dairy J. 17:791-799.

Hallén, E., A. Lundén, A.-M. Tyrisevä, M. Westerlind, and A. Andrén. 2010. Composition of poorly and non-coagulating bovine milk and effect of calcium addition. J. Dairy Res. 77:398-403.

Hallén, E., A. Wedholm, A. Andrén, and A. Lundén. 2008. Effect of $\beta$-casein, $\kappa$-casein and $\beta$-lactoglobulin genotypes on concentration of milk protein variants. J. Anim. Breed. Genet. 125:119-129.

Heck, J. M. L., C. Olieman, A. Schennink, H. J. F. van Valenberg, M. H. P. W. Visker, R. C. R. Meuldijk, and A. C. M. van Hooijdonk. 2008. Estimation of variation in concentration, phosphorylation and genetic polymorphism of milk proteins using capillary zone electrophoresis. Int. Dairy J. 18:548-555.

Heck, J. M. L., A. Schennink, H. J. F. van Valenberg, H. Bovenhuis, M. H. P. W. Visker, J. A. M. van Arendonk, and A. C. M. van Hooijdonk. 2009. Effects of milk protein variants on the protein composition of bovine milk. J. Dairy Sci. 92:1192-1202.

Ikonen, T., K. Ahlfors, R. Kempe, M. Ojala, and O. Ruottinen. 1999a. Genetic parameters for the milk coagulation properties and prevalence of noncoagulating milk in Finnish dairy cows. J. Dairy Sci. $82: 205-214$.

Ikonen, T., S. Morri, A. M. Tyriseva, O. Ruottinen, and M. Ojala. 2004. Genetic and phenotypic correlations between milk coagulation properties, milk production traits, somatic cell count, casein content and pH of milk. J. Dairy Sci. 87:458-467.

Ikonen, T., M. Ojala, and E. L. Syvaoja. 1997. Effects of composite casein and $\beta$-lactoglobulin genotypes on renneting properties and composition of bovine milk by assuming an animal model. Agric. Food Sci. Finl. 6:283-294.

Ikonen, T., O. Ruottinen, E.-L. Syväoja, K. Saarinen, E. Pahkala, and M. Ojala. 1999b. Effect of milk coagulation properties of herd bulk milks on yield and composition of Emmental cheese. Agric. Food Sci. Finl. 8:411-422.

Jakob, E., and Z. Puhan. 1992. Technological properties of milk as influenced by genetic polymorphism of milk proteins - A review. Int. Dairy J. 2:157-178.

Jann, O., G. Ceiotti, A. Caroli, and E. Erhardt. 2002. A new variant in exon VII of bovine $\beta$-casein gene (CSN2) and its distribution among European cattle breeds . J. Anim. Breed. Genet. 119:65-68.

Jensen, H. B., J. W. Holland, N. A. Poulsen, and L. B. Larsen. 2012a. Milk protein genetic variants and isoforms identified in bovine milk representing extremes in coagulating properties. J. Dairy Sci. 95:2891-2903.

Jensen, H. B., N. A. Poulsen, K. K. Andersen, M. Hammershøj, H. D. Poulsen, and L. B. Larsen. 2012b. Distinct composition of bovine milk from Jersey and Holstein-Friesian cows with good, poor or non-coagulation properties as reflected in protein genetic variants and isoforms. J. Dairy Sci. 95:6905-6917.

Jõudu, I., M. Henno, T. Kaart, T. Püssa, and O. Kärt. 2008. The effect of milk protein contents on the rennet coagulation properties of milk from individual dairy cows. Int. Dairy J. 18:964-967.

Jõudu, I., M. Henno, S. Värv, T. Kaart, O. Kärt, and K. Kalamees. 2007. Milk protein genotypes and milk coagulation properties of Estonian native cattle. Agric. Food Sci. 16:222-231.

Larsen, L. B., C. Benfeldt, L. K. Rasmussen, and T. E. Petersen. 1996. Bovine milk procathepsin D and cathepsin D: Coagulation and milk protein degradation. J. Dairy Res. 63:119-130.

Lien, S., J. Kantanen, I. Olsaker, L.-E. Holm, E. Eythorsdottir, K. Sandberg, B. Dalsgard, and S. Adalsteinsson. 1999. Comparison of milk protein allele frequencies in Nordic cattle breeds. Anim. Genet. 30:85-91.

Lundén, A., M. Nilsson, and L. Janson. 1997. Marked effect of $\beta$-lactoglobulin polymorphism on the ratio of casein to total protein in milk. J. Dairy Sci. 80:2996-3005.

Marziali, A. S., and K. F. Ng-Kwai-Hang. 1986. Relationship between milk protein polymorphisms and cheese yielding capacity. J. Dairy Sci. 69:1193-1201.

Mayer, H. K., M. Ortner, E. Tschager, and W. Ginzinger. 1997. Composite milk protein phenotypes in relation to composition and cheesemaking properties of milk. Int. Dairy J. 7:305-310.

Meza-Nieto, M. A., B. Vallejo-Cordoba, A. F. González-Córdova, L. Félix, and F. M. Goycoolea. 2007. Effect of $\beta$-lactoglobulin A and $\mathrm{B}$ whey protein variants on the rennet-induced gelation of skim milk gels in a model reconstituted skim milk system. J. Dairy Sci. 90:582-593.

Mohr, U., D. Koczan, D. Linder, G. Hobom, and G. Erhardt. 1994. A single point mutation results in A allele-specific exon skipping in the bovine alpha S1-casein mRNA. Gene 143:187-192.

Ojala, M., T. R. Famula, and J. F. Medrano. 1997. Effects of milk protein genotypes on the variation for milk production traits of Holstein and Jersey cows in California. J. Dairy Sci. 80:1776-1785.

Oloffs, K., H. Shulte-Coerne, K. Pabst, and H. O. Gravert. 1992. Die Bedeutung der Proteinvarianten für genetische Unterschiede in der Käsereitauglichkeit der Milch. Züchtungskunde 64:20-26.

Poulsen, N. A., F. Gustavsson, M. Glantz, M. Paulsson, L. B. Larsen, and M. K. Larsen. 2012. The influence of feed and herd on fatty acid composition in 3 dairy breeds (Danish Holstein, Danish Jersey, and Swedish Red). J. Dairy Sci. 95:6362-6371.

Schaar, J. 1984. Effects of $\kappa$-casein genetic variants and lactation number on the renneting properties of individual milks. J. Dairy Res. 51:397-406.

Sundekilde, U. K., P. D. Frederiksen, M. R. Clausen, L. B. Larsen, and H. C. Bertram. 2011. Relationship between metabolite profile and technological properties of bovine milk from two dairy breeds elucidated by NMR-based metabolomics. J. Agric. Food Chem. 59:7360-7367.

Threadgill, D. W., and J. E. Womack. 1990. Genomic analysis of the major bovine milk protein genes. Nucleic Acids Res. 18:69356942.

Tyrisevä, A. M., K. Elo, A. Kuusipuro, V. Vilva, I. Janonen, H. Karjalainen, T. Ikonen, and M. Ojala. 2008. Chromosomal regions 
underlying noncoagulation of milk in Finnish Ayrshire cows. Genetics 180:1211-1220.

Tyrisevä, A. M., T. Ikonen, and M. Ojala. 2003. Repeatability estimates for milk coagulation traits and non-coagulation of milk in Finnish Ayrshire cows. J. Dairy Res. 70:91-98.

Tyrisevä, A. M., T. Vahlsten, O. Routtinen, and M. Ojala. 2004. Noncoagulation of milk in Finnish Ayrshire and Holstein-Friesian cows and effect of herds on milk coagulation ability. J. Dairy Sci. 87:3958-3966.

Van Eenennaam, A., and J. F. Medrano. 1991. Milk protein polymorphisms in California dairy cattle. J. Dairy Sci. 74:1730-1742.
Visker, M. H. P. W., B. W. Dibbits, S. M. Kinders, H. J. F. van Valenberg, J. A. M. van Arendonk, and H. Bovenhuis. 2010. Association of bovine $\beta$-casein protein variant I with milk production and milk protein composition. Anim. Genet. 42:212-218.

Walstra, P. 1990. On the stability of the casein micelles. J. Dairy Sci. 73:1965-1979.

Wedholm, A., L. B. Larsen, H. Lindmark-Månsson, A. H. Karlsson, and A. Andrén. 2006. Effect of protein composition on the cheesemaking properties of milk from individual dairy cows. J. Dairy Sci. 89:3296-3305. 